\title{
Thermophilic bacteria in Moroccan hot springs, salt marshes and desert soils
}

\author{
Tarik Aanniz ${ }^{1,3}$, Mouna Ouadghiri ${ }^{1,2}$, Marouane Melloul ${ }^{5}$, Jean Swings ${ }^{4}$, \\ Elmostafa Elfahime ${ }^{5}$, Jamal Ibijbijen ${ }^{3}$, Mohamed Ismaili ${ }^{3}$, Mohamed Amar ${ }^{1,2}$ \\ ${ }^{1}$ Laboratoire de Microbiologie et Biologie Moléculaire, \\ Centre National pour la Recherche Scientifique et Technique, Rabat, Maroc. \\ ${ }^{2}$ Collections Coordonnées Marocaines de Microorganismes, Laboratoire de Microbiologie et Biologie \\ Moléculaire, Centre National pour la Recherche Scientifique et Technique, Rabat, Maroc. \\ ${ }^{3}$ Faculté des Sciences, Université Moulay Ismail, Meknès, Maroc. \\ ${ }^{4}$ Laboratory of Microbiology, Gent University, Gent, Belgium. \\ ${ }^{5}$ Unité d'Appui Technique à la Recherche Scientifique, \\ Centre National pour la Recherche Scientifique et Technique, Rabat, Maroc.
}

Submitted: March 12, 2014; Approved: September 30, 2014.

\begin{abstract}
The diversity of thermophilic bacteria was investigated in four hot springs, three salt marshes and 12 desert sites in Morocco. Two hundred and forty (240) thermophilic bacteria were recovered, identified and characterized. All isolates were Gram positive, rod-shaped, spore forming and halotolerant. Based on BOXA1R-PCR and 16S rRNA gene sequencing, the recovered isolates were dominated by the genus Bacillus (97.5\%) represented by B. licheniformis (119), B. aerius (44), B. sonorensis (33), B. subtilis (subsp. spizizenii (2) and subsp. inaquosurum (6)), B. amyloliquefaciens (subsp. amyloliquefaciens (4) and subsp. plantarum (4)), B. tequilensis (3), B. pumilus (3) and Bacillus sp. (19). Only six isolates (2.5\%) belonged to the genus Aeribacillus represented by A.pallidus (4) and Aeribacillus sp. (2). In this study, B. aerius and B. tequilensis are described for the first time as thermophilic bacteria. Moreover, $71.25 \%, 50.41 \%$ and $5.41 \%$ of total strains exhibited high amylolytic, proteolytic or cellulolytic activity respectively.
\end{abstract}

Key words: thermophilic bacteria, hot springs, diversity, 16S rRNA gene sequencing, hydrolytic enzymes.

\section{Introduction}

Extremophiles are thriving in extreme ecosystems. Such environments may have extremely high or low $\mathrm{pH}$, high or low temperatures, high salinity, high pressure and various combinations thereof. Extremophilic microorganisms include members of all three domains of life, Archaea, Bacteria and Eukarya. Many investigations focused on their potential as sources of highly active enzymes 'extremozymes' and other products such as antibiotics, compatible solutes (Robb et al., 2008).

Thermophiles are growing optimally between 55 and $80^{\circ} \mathrm{C}$, while hyperthermophiles grow above $80^{\circ} \mathrm{C}$ (Brock 1978; Bertoldo et al., 2002). They may be Gram positive or negative, spore forming or not, and may exhibit an aerobic or anaerobic metabolism. Their study has become a major domain of research and several new thermophilic genera and species have recently been described (Yoneda et al., 2013; Cihan et al., 2014). They were intensively studied due to their potential to produce thermostable enzymes (proteases, amylases, lipases, xylanases, DNA polymerases) and exo-polysaccharides (Meintanis et al., 2008; Singh et al., 2010). These thermo-enzymes are usually not only thermostable, but also active at high salinity and extreme $\mathrm{pH}$ (Gomez and Steiner, 2004).

The growth, characterization and identification of thermophiles pose specific problems (Savas et al., 2009). Development of molecular techniques such as PCR-based techniques like rep-PCR and 16S rRNA allow their reliable

Send correspondence to M. Amar. Laboratoire de Microbiologie et Biologie Moléculaire, Centre National pour la Recherche Scientifique et Technique, Angle av. Allal El Fassi, av. des FAR, Quartier Hay Ryad, BP. 8027 Nations Unies, 10102 Rabat, Maroc. E-mail: amar@cnrst.ma. 
identification, whereas conventional methods are time consuming and not reliable (Kublanov et al., 2009).

Worldwide, geothermal areas which are favorable habitats for thermophilic organisms are limited to a restrict number of sites. In Morocco, there are more than twenty hot springs distributed in different regions mainly in the Rif, the Pre-Rif and the Southern Rif (Lakhdar et al., 2006). The central region includes the hot springs of Ain Allah and Moulay Yaacoub (Fez region) and Ain Jerri (Meknes region) (Salame et al., 2013). On the South side of the Western Anti-Atlas, the Abaynou spring is located in the middle of an oasis of palms and olive trees. It is considered as the most important hot spring in South Morocco. These springs are frequently visited by Moroccans with dermal and rheumatic diseases (Salame et al., 2013). Merzouga, a small Saharan village, in South Eastern Morocco, is known for its set of sand dunes near Erg Chebbi, which is part of touristic itineraries. The climate is very hot and dry and the temperatures are often higher than $40^{\circ} \mathrm{C}$ in the day while nights are cold. In these conditions living organisms have to cope with extremes temperature, low humidity and low availability of nutritional compounds. These conditions reduce biodiversity but some bacteria developed survival strategies in order to adapt to such stress (Hecker and Völker, 2001; Bar et al., 2002).

The wetland of Sidi Moussa-Oualidia is a protected ecosystem of 10.000 ha recognized by the Ramsar Conven- tion of 2005. The complex consists of the lagoons Oualidia and Sidi Moussa and 4 salt marshes (Sidi Abed is one of them). The main activities in the neighborhood of the site are agriculture, livestock raising, sandpit exploitation, salt production, and tourism. Salt mining has reduced biodiversity, especially invertebrates (http://www.ramsar.org).

Little is known about the occurrence and distribution of thermophilic bacteria in Morocco. This work is the first study focusing on culturable thermophilic bacteria: their isolation, identification and characterization. Three kind of sites have been selected for this study i.e. hot springs, hot desert soils and salty wetland.

\section{Materials and Methods}

\section{Sampling sites}

The location of the sampling sites is shown in Figure 1 and Table 1. Their physico-chemical parameters are given in Table 1. Thirty three samples were collected in sterile conditions, then were transported to the laboratory, using thermal boxes, and immediately analyzed (Malkawi and Al-Omari, 2010).

Temperature and $\mathrm{pH}$ of the sites were measured during sampling. The total salt concentration was determined by titration using Mohr's method (Skoog et al., 1996).

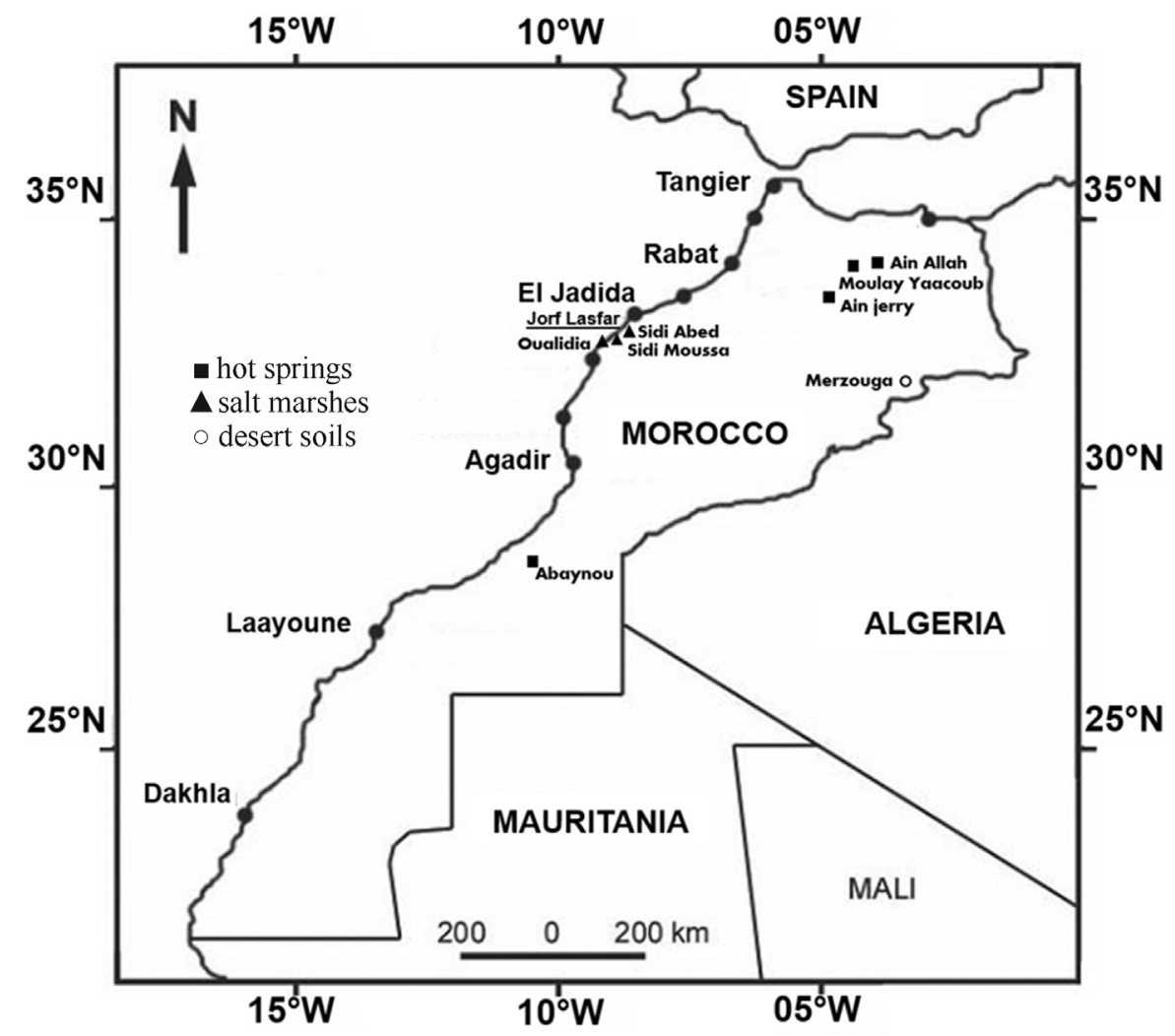

Figure 1 - Location of the studied sites. 
Table 1 - Physico-chemical parameters in the sampling sites.

\begin{tabular}{|c|c|c|c|c|c|}
\hline Biotopes & Sampling sites & $\mathrm{T}\left({ }^{\circ} \mathrm{C}\right)$ & $\mathrm{pH}$ & $\% \mathrm{NaCl}(\mathrm{w} / \mathrm{v})$ & Geographical references \\
\hline \multirow[t]{8}{*}{ Hot springs } & Ain Allah & 45 & 7.3 & - & $34^{\circ} 2^{\prime} 19.76^{\prime \prime} \mathrm{N}$ \\
\hline & & & & & $5^{\circ} 8 ’ 13.18^{\prime \prime} \mathrm{O}$ \\
\hline & Abaynou & 39 & 7.4 & - & $29^{\circ} 5^{\prime} 26^{\prime \prime} \mathrm{N}$ \\
\hline & & & & & $10^{\circ} 1 ' 27^{\prime \prime} \mathrm{W}$ \\
\hline & Moulay Yaacoub & 57 & 7 & - & $34^{\circ} 5^{\prime} 16^{\prime \prime} \mathrm{N}$ \\
\hline & & & & & $5^{\circ} 10^{\prime} 52^{\prime \prime} \mathrm{O}$ \\
\hline & Ain Jerri & 39 & 7.2 & - & $33^{\circ} 50^{\prime} 30.28^{\prime \prime} \mathrm{N}$ \\
\hline & & & & & $5^{\circ} 40^{\prime} 2.41 ” \mathrm{O}$ \\
\hline \multirow[t]{6}{*}{ Salt Marshes } & Sidi Moussa & 19 to 22 & 7.6 to 7.7 & 7.1 to 9 & $33^{\circ} 01^{\prime} \mathrm{N}$ \\
\hline & & & & & $08^{\circ} 44^{\prime} \mathrm{W}$ \\
\hline & Sidi Abed & 16.5 to 18 & 8.2 to 8.4 & 3.2 to 10.8 & $33^{\circ} 02^{\prime} \mathrm{N}$ \\
\hline & & & & & $08^{\circ} 42^{\prime} \mathrm{W}$ \\
\hline & Oualidia & 18.5 to 20 & 7.9 to 8.2 & 1.9 to 3.8 & $32^{\circ} 46^{\prime} \mathrm{N}$ \\
\hline & & & & & $09^{\circ} 01^{\prime} \mathrm{W}$ \\
\hline \multirow[t]{2}{*}{ Desert soil } & Merzouga & 34 to 47 & - & - & $31^{\circ} 05^{\prime} 57^{\prime \prime} \mathrm{N}$ \\
\hline & & & & & $4^{\circ} 00^{\prime} 42^{\prime \prime} \mathrm{O}$ \\
\hline
\end{tabular}

\section{Enumeration and isolation of thermophilic bacteria}

\section{Sand samples}

An amount of $15 \mathrm{~g}$ of each sand sample was homogenized in $15 \mathrm{~mL}$ of sterile saline solution $(0.9 \% \mathrm{NaCl}(\mathrm{w} / \mathrm{v}))$. Tenfold dilutions were prepared using sterile saline solution. From each dilution, $100 \mu \mathrm{L}$ were plated on Tryptone Soy Agar (TSA, Difco, Detroit, USA) and incubated at $55^{\circ} \mathrm{C}$ for $96 \mathrm{~h}$. The assay was done in triplicate.

\section{Water samples}

For each water sample, $100 \mathrm{~mL}$ were filtered through membrane filters $(0.22 \mu \mathrm{m}$ Millipore Corporation, Bedford); the filters were placed onto TSA and incubated at $55^{\circ} \mathrm{C}$ for $96 \mathrm{~h}$ in triplicate under aerobic conditions (Maugeri et al., 2001; Malkawi and Al-Omari, 2010).

Bacterial colonies with different morphologies were picked up and plated on TSA until pure cultures were obtained. Numbers were expressed as colony forming units (cfu) (Khiyami et al., 2012). Purified colonies were cultivated on Tryptone Soy Broth (TSB, Difco, Detroit, USA), stored in $20 \%$ of glycerol at $-80{ }^{\circ} \mathrm{C}$, freeze-dried for further studies and deposited in the Moroccan Coordinated Collections of Microorganisms (www.ccmm.ma).

\section{Phenotypic study}

Characterization of each isolate was performed by observation of its colony morphology, color, size, elevation, margin and Gram and malachite green spore staining. Presence of catalase and oxidase were investigated according to the methods described by Prescott et al. (2003).

The ability to grow at different temperatures was evaluated by plating onto TSA and incubating at 55, 60, 65,
70,75 and $80{ }^{\circ} \mathrm{C}$ for $48 \mathrm{~h}$. Halotolerance was assayed by plating each culture onto TSA supplemented with $\mathrm{NaCl}$ to total concentrations of 0.5 to $15 \%(\mathrm{w} / \mathrm{v})$ and incubating at $55^{\circ} \mathrm{C}$ for $48 \mathrm{~h}$. Growth was determined by visual observation and all tests were made in triplicate.

Proteolytic and cellulolytic activities were screened qualitatively as described by Sadfi-Zouaoui et al. (2008). Amylolytic activity was tested according to Cowan (1991). Lipolytic and cellulolytic activities were revealed according to Sierra (1957). The screening was performed in triplicate.

\section{Genotypic study}

BOXA1R-PCR has been used to cluster all obtained thermophilic isolates. Representative isolates of each cluster were subjected to $16 \mathrm{~S}$ rRNA gene sequencing.

\section{DNA extraction and BOXA1R-PCR fingerprinting}

Total DNA extraction was performed as described by Pitcher et al. (1989). DNA primers corresponding to BOX elements sequences were used as described by Versalovic et al. (1994). The PCR products were separated by electrophoresis on $1.5 \%$ agarose gels at $35 \mathrm{~V}$ for $18 \mathrm{~h}$ at $4{ }^{\circ} \mathrm{C}$. BOXA1R-PCR gels stained were visualized under ultraviolet light, followed by digital image capturing using a CCD camera (CCD Camera 570 LTV-Gel SMART, France). These fingerprints were analyzed using BioNumerics software package v6.6 (Applied Maths, Sint Martens Latem, Belgium). Similarity among the digitized profiles was calculated using the Pearson correlation coefficient, and an average linkage (UPGMA) dendrogram was derived (Cherif et al., 2002; De Clerck and De Vos, 2004). 
$16 S$ rRNA gene sequencing and phylogenetic analysis

A set of 144 representative isolates were selected for 16S rRNA gene sequencing using the primers fD1 (5'AGAGTTTGATCCTGGCTCAG-3') and rP2 (5'-TACGG CTACCTTGTTACGACTT- 3'). Cleaned PCR products were used as a template for the cycle sequencing reaction (Berrada et al., 2012).

Forward and reverse sequencing were performed using Big Dye Terminator version 3.1 cycle sequencing kit (Applied Biosystems, Foster City, CA) according to the manufacturer's instructions. Sequences assembled were checked and corrected and a preliminary identification was performed by FASTA search of the NCBI database. For a more precise identification, the 16S rRNA sequences were also compared with the prokaryotic small subunit rRNA sequence of the Ez-Taxon database (Kim et al., 2012). The Type and reference strains with highest similarity to the sequences of the studied isolates were retrieved and introduced in BioNumerics database. 16S rRNA sequences were aligned and compared to each other using BioNumerics, and a phylogenetic tree was constructed using the UPGMA algorithm. Isolates were regarded as belonging to a species when sequence similarity with the species type strain was at least $99 \%$ and to a genus when sequence similarity with a type strain was at least $97 \%$ (Berrada et al., 2012). The 16S rRNA gene sequences, determined in this study, have been deposited in the Genbank database under the accession numbers KF879189 - KF879333.

\section{Results}

\section{Sampling sites}

Eight sites were prospected in Morocco between March 2009 and July 2010: 4 hot springs (Ain Allah, Moulay Yaacoub, Ain Jerri and Abaynou), 3 salt marshes (Sidi Moussa, Sidi Abed and Oualidia), and the desert soils of Merzouga (Figure 1). Temperature values were between 34 and $47^{\circ} \mathrm{C}$ in the desert soils, while in hot springs they were between 39 and $57^{\circ} \mathrm{C}$. For salt marshes they were between 16.5 and $22^{\circ} \mathrm{C}$. In hot springs $\mathrm{pH}$ values were be- tween 7.1 and 7.4 and in salt marshes they were between 7.6 and 8.4. The average salt concentration varied in salt marshes from $1.9 \% \mathrm{NaCl}(\mathrm{w} / \mathrm{v})$ in Oualidia to $10.8 \%(\mathrm{w} / \mathrm{v})$ in Sidi Abed (Table 1).

\section{Thermophilic isolates}

The colony forming unit of thermophilic bacteria that grew on TSA at $55^{\circ} \mathrm{C}$, varied from $0.5 \times 10^{2}$ to $1.2 \times 10^{3} \mathrm{cfu}$ $\mathrm{mL}^{-1}$ in hot springs, from $1.1 \times 10^{2}$ to $1.0 \times 10^{3} \mathrm{cfu} \mathrm{mL}^{-1}$ in salt marshes and was around $5 \times 10^{3} \mathrm{cfu} \mathrm{g}^{-1}$ in desert. A set of 240 isolates was obtained: 108 isolates from desert (45\%), 79 from hot springs (33\%) and 53 from salt marshes (22\%) (Table 2).

Of the 240 isolates, $235(97.9 \%)$ were beige-colored, 3 were white and 2 were yellow on TSA. All of the isolates were thermophilic (optimal growth up to $55^{\circ} \mathrm{C}$ ), Gram positive, rod-shaped, endospore forming and halotolerant (grew between $0.5 \%$ and $10 \% \mathrm{NaCl}(\mathrm{w} / \mathrm{v}), 225$ isolates $(93.75 \%)$ were catalase and oxidase positive.

\section{BOXA1R-PCR fingerprinting}

The dendogram derived from the BOXA1R-PCR fingerprints (Figure 2) showed 15 clusters (numbered from $\mathrm{C} 1$ to $\mathrm{C} 15$ ). Cluster analysis revealed a complex set of relatedness of BOXA1R-PCR patterns among the thermophilic isolates belonging to the same cluster, suggesting a rich population diversity. Only 53 isolates were identified by BOXA1R-PCR when the profiles were compared to those of the reference and type strains available in the CCMM database: 44 isolates were identified as $B$. licheniformis (cluster 7), 4 isolates as $B$. amyloliquefaciens subsp. amyloliquefaciens (cluster 4), 3 isolates as B. pumilus (cluster 2) and 2 isolates were identified as B. subtilis subsp. spizizenii (cluster 1) (Figure 2). This identification was confirmed by further 16S rRNA analysis.

\section{S rRNA gene sequencing analysis}

In the second step of the genotypic identification, 144 representatives of the 15 clusters and ungrouped isolates were subjected to total $16 \mathrm{~S}$ rRNA gene sequencing. Sequence analysis of 119 isolates showed a high similarity

Table 2 - Bacteria count and number of isolates in the sampling sites.

\begin{tabular}{lcccc}
\hline Biotopes & Sampling sites & cfu/l or cfu/g & Number of isolates & \% of thermophilic isolates \\
\hline Hot springs & Ain Allah & $610^{2}$ & 31 & $12.9 \%$ \\
& Abaynou & $1.210^{3}$ & 30 & $12.5 \%$ \\
& Moulay Yaacoub & $0.510^{2}$ & 5 & $2 \%$ \\
Salt Marshes & Ain Jerri & $10^{3}$ & 13 & $5.41 \%$ \\
& Sidi Moussa & $10^{3}$ & 16 & $6.66 \%$ \\
Desert soil & Sidi Abed & $410^{2}$ & 27 & $11.25 \%$ \\
& Oualidia & $1.110^{2}$ & 10 & $4.16 \%$ \\
\hline
\end{tabular}



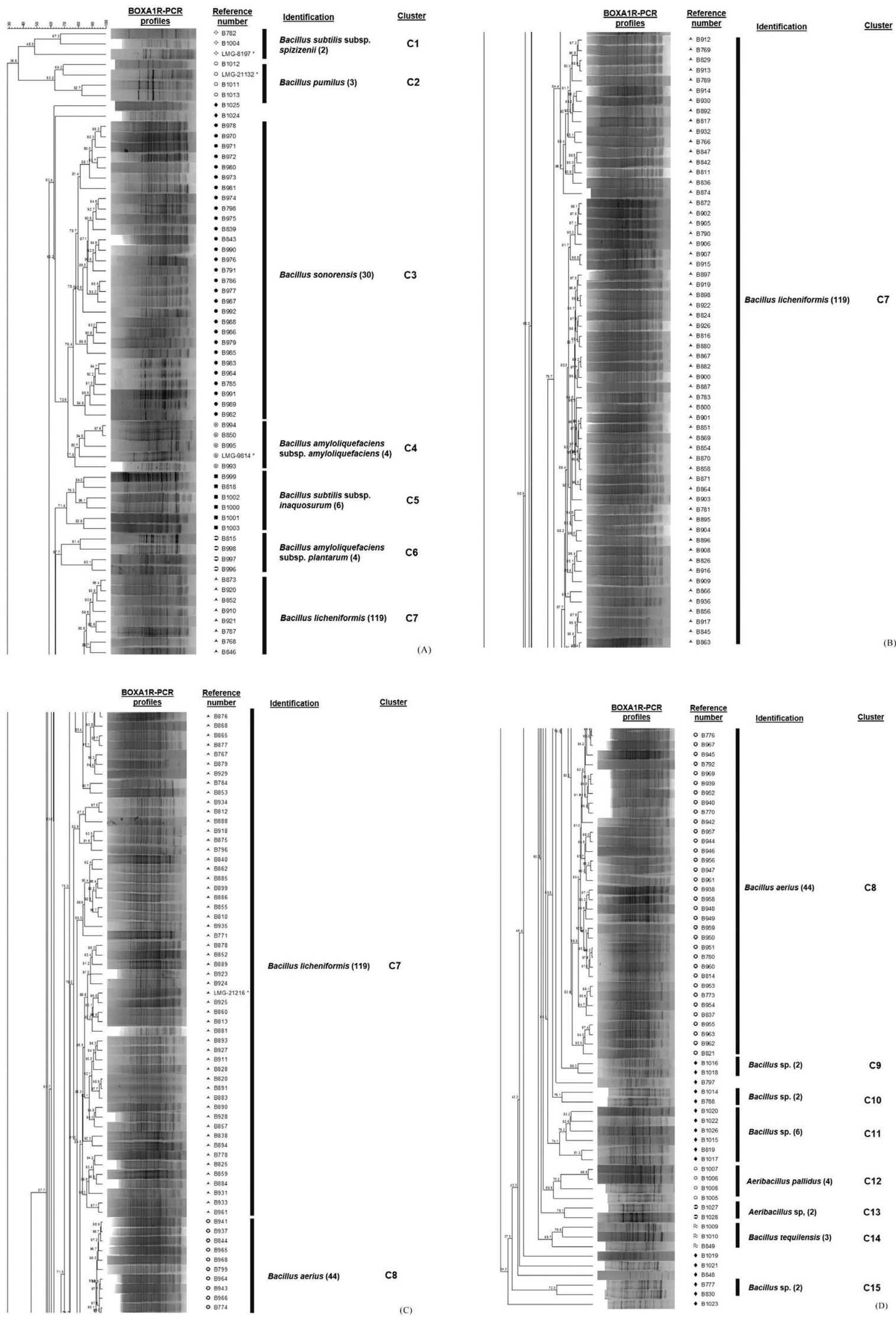

Figure 2 - Cluster analysis of BOXA1R-PCR fingerprints and 16S gene sequencing of thermophilic bacteria strains. The dendrogram was generated by the UPGMA method and Pearson correlation coefficient. LMG strains are reference strains used for identification * = reference strain. 
$(\geq 99 \%)$ with those of the reference strains available in the Genbank and Ez-taxon databases. Moreover, 21 isolates showed moderate sequence similarity (97 to 98.9\%) (Table 3 ) indicating that they may be potential new species.

The combination of the BOXA1R-PCR and 16S rRNA gene sequencing allowed identifying 219 isolates to the species level. The results revealed a clear domination of the genus Bacillus represented by 234 isolates i.e. B. licheniformis, B. aerius, B. sonorensis, B. subtilis (subsp. spizizenii and subsp. inaquosurum), B. amyloliquefaciens (subsp. amyloliquefaciens and subsp. plantarum), $B$. tequilensis, B. pumilus and Bacillus sp. In addition, 6 isolates belonged to the genus Aeribacillus i.e. A. pallidus and Aeribacillus sp. (Figure 2, Table 4). The repartition of the obtained species is presented in Table 4.

Five Bacillus species (B. licheniformis, B. aerius, $B$. sonorensis, $B$. subtilis and $B$. amyloliquefaciens) were common between hot springs, salt marshes and desert soils (Table 4). A total of 8 species were identified in hot springs and seven in desert soils but $B$. licheniformis was the most abundant species (48.1\% and $45.37 \%$ respectively). Five species were recovered in salt marshes with $B$. licheniformis as a dominant species (60.4\%).

\section{Effect of temperature}

The number of growing strains is reduced between $55^{\circ} \mathrm{C}$ and $65^{\circ} \mathrm{C}$, while it's drastically reduced at $70{ }^{\circ} \mathrm{C}$ and over. Only 4 isolates tolerate $75^{\circ} \mathrm{C}$ and none was able to grow at $80^{\circ} \mathrm{C}$. The number of strains growing at the different temperatures tested are given in Table 5.

\section{Effect of salinity}

The number of strains growing is reduced with salt concentration increased in the medium. All isolates grew at $3 \% \mathrm{NaCl}(\mathrm{w} / \mathrm{v}), 220(91.67 \%)$ grew at $5 \% \mathrm{NaCl}(\mathrm{w} / \mathrm{v}), 183$ $(76.25 \%)$ grew at $10 \% \mathrm{NaCl}(\mathrm{w} / \mathrm{v})$, and none at $15 \% \mathrm{NaCl}$ (w/v) (Table 6).

\section{Production of thermo-enzymes}

Of the 240 strains, $205(85.42 \%)$ produced at least one extracellular hydrolytic enzyme: 171 strains $(71.25 \%)$ produced amylases, 121 strains $(50.41 \%)$ produced proteases and only 16 strains $(6.67 \%)$ produced cellulases. None of the isolates produced lipases. In addition, 9 strains $(3.75 \%)$ combined the three tested enzymes and 85 strains $(35.41 \%)$ produced two enzymes (Table 7$) .35$ strains produced none of the enzymes screened.

Table 3 - 16S gene sequencing data for the identified strains to the genus level compared to the type strains.

\begin{tabular}{lcl}
\hline CCMM N $^{\circ}$ & \% of similarity & Reference strains \\
\hline $\begin{array}{l}\text { B777, B788, B830, B848 B1014, B1020, B1022, B1023, B1024 } \\
\text { and B1025 }\end{array}$ & 97.82 to 98.93 & Bacillus sonorensis DSM 13779 \\
B797, B819, B1015, B1016, B1017 and B1026 & 98.42 to 98.99 & Bacillus licheniformis ATCC 14580 \\
B1019 and B1021 & 97.95 to 98.37 & Bacillus subtilis subsp. inaquosorum NRRL B-23052 \\
B1018 & 97.58 & Bacillus aerius JCM 13348 \\
B1027 and B1028 & 97.31 to 97.71 & Aeribacillus pallidus ATCC 51176 \\
\hline
\end{tabular}

Table 4 - Biotope, sampling site and distribution of thermophilic bacteria.

\begin{tabular}{|c|c|c|c|c|c|c|c|c|c|}
\hline \multirow[t]{2}{*}{ Identified species } & \multirow{2}{*}{$\begin{array}{l}\text { Number of } \\
\text { strains (\%) }\end{array}$} & \multicolumn{8}{|c|}{ Distribution per origin } \\
\hline & & Merzouga & $\begin{array}{l}\text { Sidi } \\
\text { Abed }\end{array}$ & $\begin{array}{c}\text { Sidi } \\
\text { Moussa }\end{array}$ & Oualidia & Abaynou & $\begin{array}{l}\text { Ain } \\
\text { Allah }\end{array}$ & $\begin{array}{l}\text { Ain } \\
\text { Jerri }\end{array}$ & $\begin{array}{l}\text { Moulay } \\
\text { Yaacoub }\end{array}$ \\
\hline B. licheniformis & $119(49.58 \%)$ & 49 & 15 & 10 & 7 & 9 & 14 & 10 & 5 \\
\hline B. aerius & $44(18.33 \%)$ & 23 & 5 & 4 & 3 & 7 & 2 & & \\
\hline B. sonorensis & $30(12.5 \%)$ & 11 & 4 & 2 & 8 & 4 & 1 & & \\
\hline B. subtilis & $8(3.33 \%)$ & 3 & 2 & 2 & 1 & & & & \\
\hline B. amyloliquefaciens & $8(3.33 \%)$ & 4 & 1 & 1 & 2 & & & & \\
\hline B. tequilensis & $3(1.25 \%)$ & 1 & 1 & 1 & & & & & \\
\hline B. pumilus & $3(1.25 \%)$ & 1 & 2 & & & & & & \\
\hline A. pallidus & $4(1.66 \%)$ & 4 & & & & & & & \\
\hline Bacillus sp. & $19(7.9 \%)$ & 15 & 3 & 1 & & & & & \\
\hline Aeribacillus sp. & $2(0.83 \%)$ & 1 & 1 & & & & & & \\
\hline Total & 240 & 108 & 27 & 16 & 10 & 30 & 31 & 13 & 5 \\
\hline
\end{tabular}


Table 5 - Effect of temperature on growth of different species.

\begin{tabular}{|c|c|c|c|c|c|c|c|}
\hline Species & $30^{\circ} \mathrm{C}$ & $55^{\circ} \mathrm{C}$ & $60^{\circ} \mathrm{C}$ & $65^{\circ} \mathrm{C}$ & $70^{\circ} \mathrm{C}$ & $75^{\circ} \mathrm{C}$ & $80^{\circ} \mathrm{C}$ \\
\hline B. licheniformis & $119 / 119^{a}$ & $119 / 119$ & $114 / 119$ & $72 / 119$ & $5 / 119$ & $3 / 119$ & $0 / 119$ \\
\hline B. aerius & $44 / 44$ & $44 / 44$ & $39 / 44$ & $26 / 44$ & $1 / 44$ & $1 / 44$ & $0 / 44$ \\
\hline B. sonorensis & $30 / 30$ & $30 / 30$ & $25 / 30$ & $11 / 30$ & $1 / 30$ & $0 / 30$ & $0 / 30$ \\
\hline B. subtilis & $8 / 8$ & $8 / 8$ & $7 / 8$ & $5 / 8$ & $0 / 8$ & $0 / 8$ & $0 / 8$ \\
\hline B. amyloliquefaciens & $8 / 8$ & $8 / 8$ & $3 / 8$ & $2 / 8$ & $0 / 8$ & $0 / 8$ & $0 / 8$ \\
\hline B. tequilensis & $3 / 3$ & $3 / 3$ & $2 / 3$ & $1 / 3$ & $0 / 3$ & $0 / 3$ & $0 / 3$ \\
\hline B. pumilus & $3 / 3$ & $3 / 3$ & $1 / 3$ & $0 / 3$ & $0 / 3$ & $0 / 3$ & $0 / 3$ \\
\hline A. pallidus & $4 / 4$ & $4 / 4$ & $4 / 4$ & $4 / 4$ & $3 / 4$ & $0 / 4$ & $0 / 4$ \\
\hline Bacillus sp. & $19 / 19$ & $19 / 19$ & $19 / 19$ & $4 / 19$ & $1 / 19$ & $0 / 19$ & $0 / 19$ \\
\hline Aeribacillus sp. & $2 / 2$ & $2 / 2$ & $2 / 2$ & $0 / 2$ & $0 / 2$ & $0 / 2$ & $0 / 2$ \\
\hline Total & 240 & 240 & 216 & 125 & 11 & 4 & 0 \\
\hline
\end{tabular}

${ }^{a} \mathrm{xi} / \mathrm{yi}$, where $\mathrm{xi}=$ number of strains growing at mentioned temperature and $\mathrm{yi}=$ total number of strains.

Table 6 - Influence of salinity $(\% \mathrm{NaCl}(\mathrm{w} / \mathrm{v}))$ on growth of different species.

\begin{tabular}{lccccc}
\hline Species & $0.5 \%$ & $3 \%$ & $5 \%$ & $10 \%$ & $15 \%$ \\
\hline B. licheniformis & $119 / 119^{\mathrm{b}}$ & $119 / 119$ & $114 / 119$ & $97 / 119$ & $0 / 119$ \\
B. aerius & $44 / 44$ & $44 / 44$ & $40 / 44$ & $31 / 44$ & $0 / 44$ \\
B. sonorensis & $30 / 30$ & $30 / 30$ & $26 / 30$ & $21 / 30$ & $0 / 30$ \\
B. subtilis & $8 / 8$ & $8 / 8$ & $6 / 8$ & $6 / 8$ & $0 / 8$ \\
B. amyloliquefaciens & $8 / 8$ & $8 / 8$ & $7 / 8$ & $3 / 8$ & $0 / 8$ \\
B. tequilensis & $3 / 3$ & $3 / 3$ & $2 / 3$ & $1 / 3$ & $0 / 3$ \\
B. pumilus & $3 / 3$ & $3 / 3$ & $1 / 3$ & $1 / 3$ & $0 / 3$ \\
A. pallidus & $4 / 4$ & $4 / 4$ & $3 / 4$ & $2 / 4$ & $0 / 4$ \\
Bacillus sp. & $19 / 19$ & $19 / 19$ & $19 / 19$ & $19 / 19$ & $0 / 19$ \\
Aeribacillus sp. & $2 / 2$ & $2 / 2$ & $2 / 2$ & $2 / 2$ & $2 / 2$ \\
Total & 240 & 240 & 220 & 183 & 0 \\
\hline
\end{tabular}

${ }^{b} \mathrm{xi} / \mathrm{yi}$, where $\mathrm{xi}=$ number of strains growing at mentioned $\% \mathrm{NaCl}(\mathrm{w} / \mathrm{v})$ and $\mathrm{yi}=$ total number of strains.

Table 7 - Production of thermo-enzymes.

\begin{tabular}{lccccccc}
\hline Species & $\mathrm{C} 1$ & $\mathrm{C} 2$ & $\mathrm{C} 3$ & $\mathrm{C} 4$ & $\mathrm{C} 5$ & $\mathrm{C} 6$ & $\mathrm{C} 7$ \\
\hline B. licheniformis & $37 / 119^{\mathrm{c}}$ & $17 / 119$ & $38 / 119$ & $3 / 119$ & $0 / 119$ & $5 / 119$ & $19 / 119$ \\
B. aerius & $14 / 44$ & $6 / 44$ & $15 / 44$ & $1 / 44$ & $1 / 44$ & $1 / 44$ & $6 / 44$ \\
B. sonorensis & $6 / 30$ & $4 / 30$ & $12 / 30$ & $0 / 30$ & $1 / 30$ & $2 / 30$ & $5 / 30$ \\
B. subtilis & $1 / 8$ & $2 / 8$ & $3 / 8$ & $0 / 8$ & $0 / 8$ & $1 / 8$ & $1 / 8$ \\
B. amyloliquefaciens & $4 / 8$ & $0 / 8$ & $4 / 8$ & $0 / 8$ & $0 / 8$ & $0 / 8$ & $0 / 8$ \\
B. tequilensis & $1 / 3$ & $0 / 3$ & $2 / 3$ & $0 / 3$ & $0 / 3$ & $0 / 3$ & $0 / 3$ \\
B. pumilus & $0 / 3$ & $2 / 3$ & $1 / 3$ & $0 / 3$ & $0 / 3$ & $0 / 3$ & $0 / 3$ \\
Aeribacillus pallidus & $1 / 4$ & $0 / 4$ & $1 / 4$ & $0 / 4$ & $0 / 4$ & $0 / 4$ & $2 / 4$ \\
Bacillus sp. & $15 / 19$ & $1 / 19$ & $1 / 19$ & $1 / 19$ & $0 / 19$ & $0 / 19$ & $1 / 19$ \\
Aeribacillus sp. & $0 / 2$ & $0 / 2$ & $1 / 2$ & $0 / 2$ & $0 / 2$ & $0 / 2$ & $1 / 2$ \\
Total & 79 & 32 & 78 & 5 & 2 & 9 & 35 \\
\hline
\end{tabular}

${ }^{c} \mathrm{xi} / \mathrm{yi}$, where $\mathrm{xi}=$ number of strains producing enzymes and $\mathrm{yi}=$ total number of strains.

C1: amylases, C2: proteases, C3: amylases and proteases, C4: amylases and cellulases, C5: proteases and cellulases, C6: amylases, proteases and cellulases, C7: No enzymes. 


\section{Discussion}

Thermophilic bacteria were present in all samples analyzed. Nevertheless, total counts were very low (50$5000 \mathrm{cfu} \mathrm{mL}^{-1}$ ). In a recent study of thermophilic bacteria in ten Saudi Arabia hot springs, Khiyami et al. (2012) reported the same order of magnitude $\left(170-1320 \mathrm{cfu} \mathrm{mL}^{-1}\right)$. Despite all of the recovered strains can grow at $30^{\circ} \mathrm{C}$, but their optimal growth temperature is $55^{\circ} \mathrm{C}$ (temperature of isolation). Thus, all strains could be classified as thermophilic by Brock (1978), Souza and Martins (2001) and Cihan et al. (2012). Based on the optimal concentration of salt and according to Kushner et al. (1985), all the isolated strains were halotolerants. Morphologic, physiologic and microscopic characteristics of recovered isolates were consistent with the description of the genus Bacillus, according to Gordon et al. (1973) and Souza and Martins (2001). High number of isolates obtained in desert (108 isolates) and hot springs (79 isolates) could be explained by the hot conditions (temperature ranging from $34{ }^{\circ} \mathrm{C}$ to $57^{\circ} \mathrm{C}$ ) in these biotopes exerting a pressure for the selection of thermophilic flora mostly while in salt marshes characterized by mesophilic conditions (temperature ranging from $16.5^{\circ} \mathrm{C}$ to $22^{\circ} \mathrm{C}$ ) only 53 isolates were recovered.

Based on BOXA1R-PCR or/and 16S rRNA sequence analysis, $97.5 \%$ of isolates were assigned to the genus $B a$ cillus and $2.5 \%$ to the genus Aeribacillus. Their combination allowed identifying 219 isolates $(91.25 \%)$ to the species level (Figure 2 and Table 4), indicating that these techniques were not only a powerful tool for identification of thermophilic bacteria to the species level but also revealed a considerable intra-species diversity (De Clerck and De Vos, 2004; Adiguzel et al., 2009). Twenty one isolates remained unidentified to the species level; nineteen were assigned to Bacillus sp. and two to Aeribacillus sp. This could be an indication for the presence of potential new thermophilic species. These isolates need to be further analyzed.

The dendrogram derived from BOXA1R-PCR profiles showed a high discriminatory level and revealed 2 sub-groups among $B$. licheniformis. This is in agreement with the finding of De Clerck and De Vos (2004). Moreover, Manachini et al. (1998) while studying 182 B. licheniformis strains reported three distinct groups that were therefore regarded as genomovars of $B$. licheniformis. Our BOXA1R profiles were helpful in distinguishing between sub-species of $B$. subtilis (subsp. spizizenii and subsp. inaquosurum) and also B. amyloliquefaciens (subsp. amyloliquefaciens and subsp. plantarum). This is in agreement with the grouping reported by Connor et al. (2010).

Physiological behavior of the identified strains showed several differences between strains of the same species, such as tolerance to $\mathrm{NaCl}$, temperature and production of hydrolytic thermo-enzymes. This finding is in agreement with previous reports (Burgess et al., 2010; Adiguzel et al., 2011).

\section{Diversity recovered}

The extent of bacterial diversity detected in this study is not surprising as the majority of bacteria found in the investigated biotope occur commonly in the environment and have been described in many different environments studied elsewhere. Strains of the genus Bacillus are well adapted to hot and dry environments (Meintanis et al., 2008; Kawasaki et al., 2012). They have also generally simple nutritional needs. Therefore, they do not require specific nutrients for growth and are able to colonize oligotrophic niches like salt marshes, hot springs and desert soils (Cihan et al., 2012; Khiyami et al., 2012). Nevertheless, $B$. aerius and $B$.tequilensis were reported, for the first time, as thermophilic bacteria in this study.

Malkawi et al. (2010), reported that $97 \%$ of the recovered thermophilic isolates belong to the genus Bacillus. Abou-Shanab (2007) identified 13 thermophilic strains, from several Jordanian hot springs, belonging to the genus Bacillus (B. licheniformis and B. pumilus). In another study, Maugeri et al. (2001), isolated 87 thermophilic, aerobic and spore-forming bacteria from Eolian Islands (Italy). Most of them were members of Bacillus. Kawasaki et al. (2012) isolated 12 thermophilic bacteria belonging to the genus Bacillus, from a saline hot spring in Japan. They were also relatively halotolerant (grew in a medium with $10 \% \mathrm{NaCl}(\mathrm{w} / \mathrm{v}))$ which is consistent with our finding. Moreover, Perfumo and Marchant (2010) reported the presence of thermophilic Aeribacillus strains in samples of dust collected from Turkey and Greece. The presence of thermophilic strains belonging to $A$. pallidus from hot springs was reported by Chamkha et al. (2008) and Savas et al. (2009).

Bacillus licheniformis was the dominant species (approximately $50 \%$ of total strains), which is in agreement with those obtained by Derekova et al. (2008). Thermophilic strains of $B$. pumilus, $B$. amyloliquefaciens and $B$. subtilis have been isolated from hot springs, salt lakes, volcanic area in Turkey, Bulgaria, Iceland, Jordan, Egypt (Meintanis et al., 2008; Minana-Galbis et al., 2010 ; Cihan et al., 2012). Ngoc-Phuc et al. (2007) reported the dominance of $B$. licheniformis and also the presence of $B$. subtilis in a Japanese desert. Lester et al. (2007) reported the presence of $B$. subtilis and B. pumilus from extreme arid Atacama Desert soils. In Morocco, Berrada et al. (2012), showed that salt marshes in the north of Morocco are colonized by a number of halo-thermophilic bacteria belonging especially to B. pumilus and B. licheniformis. Bacillus sonorensis is commonly observed in arid areas, such as the Sahara, Mojave, Sonoran, and Gobi Deserts (Palmisano et al., 2001).

\section{Distribution of thermophilic bacteria}

The genus Bacillus was isolated from the 8 explored biotopes and the genus Aeribacillus was obtained only in the hot spring of Abaynou and desert of Merzouga. The oc- 
currence of Bacillus strains in all investigated sites could be explained by the fact that Bacillus has been shown to migrate at extremely high rates, even between continents, and because Bacillus spores are known to resist to the environmental stress (Connor et al., 2010). B. licheniformis was isolated from all sites and was also the unique species identified in the site of Moulay Yaacoub and Oualidia. B. licheniformis is an ubiquitously occurring spore-forming bacterium widely distributed as a saprophytic organism in the environment (Manachini et al., 1998; Rey et al., 2004).

The diversity obtained from the sand of Merzouga and the hot spring of Abaynou was very close (both located in a Saharan area) which could be explained by the perpetual movement of sand particles shipped with the wind and carried microorganisms attached thereto (Perfumo and Marchant, 2010). The low diversity detected in Moulay Yaacoub (only 5 strains belonging to $B$. licheniformis) could be explained by the high temperature $\left(57^{\circ} \mathrm{C}\right)$ and mineralization and also the oligotrophic statute of this hot spring (Lakhdar et al., 2006; Salame et al., 2013). Tekere et al. (2012), recovered a few bacteria phylotypes at Tshipise hot spring, where high temperature $\left(58^{\circ} \mathrm{C}\right)$ and high dissolved mineral salts occurred, which is consistent with our finding. It could be also explained by their composition in gases dominated by nitrogen, methane and carbon dioxide. Moreover, it has been reported that oxygen is only present in traces (Lakhdar et al., 2006). This could inhibit the development of aerobic flora (Bacillus, Aeribacillus, Geobacillus) and promotes more probably anaerobic flora (Clostridium, Anaerobaculum, Thermoanaerobacter, Thermoanaerobacterium) (Robb et al., 2008).

A total of five identified species belonging to the genus Bacillus were recovered in all the three salt marshes while three other isolates remain unidentified. This relatively low diversity could be explained by the negative effect of high content of salt in these sites resulting in reducing biodiversity (Ventosa et al., 1998). The three sites are also situated in a Moroccan region with intense agricultural activity. The use of chemical pesticides could reduce diversity of all organisms mainly bacteria. The number of different species obtained from Oualidia was less than those from Sidi Abed and Sidi Moussa. The site of Oualidia (located in direct contact with marine water) is influenced by the quality of marine water with increasing quantities of heavy metals ( $\mathrm{Pb}, \mathrm{Cd}, \mathrm{Zn}, \mathrm{Cr}, \mathrm{As})$. Atlantic Moroccan coast is characterized by lead contamination that occurs around areas receiving industrial waste outflows, mainly zone situated near the discharge from phosphate transformation industries located at Jorf Lasfar (region of El Jadida) which is very close to the marshes sampling sites (Figure 1) (Benbrahim et al., 2006).

\section{Production of thermo-enzymes}

It has been reported that thermophilic bacteria, mainly Bacillus strains, produced high valuable thermo- enzymes (Meintanis et al., 2008). In accordance with their saprophytic life style, the secretome of Bacillus strains encodes numerous secreted enzymes that hydrolyze polysaccharides, proteins, lipids and other nutrients (Rey et al., 2004). Strains obtained in this study produced an assortment of extracellular enzymes that may contribute to nutrient cycling in nature (Rey et al., 2004). In this work, $70.83 \%$ and $50.41 \%$ of total strains recovered exhibited high amylolytic and proteolytic activity respectively. While, only 19 strains $(5.41 \%)$ produced cellulases. In addition, 9 strains (3.75\%) belonging to $B$. licheniformis (5), B. aerius (1), B. sonorensis (2) and B. subtilis (1) produced all the extracellular hydrolytic enzymes screened except lipase. This finding indicated also that the tested strains may have developed genetic and physiological capability for utilizing available organic matter, via exo-enzymes production (Berrada et al., 2012). It could be also explained by trend of microbial societies toward surviving at low organic content in such niches and development of adaptable system for uptake of any available food (Derekova et al., 2008).

\section{Conclusion}

This is the first investigation of thermophilic bacteria in Moroccan hot springs, salt marshes and desert. The results showed a clear domination of thermophilic Bacillus species mainly $B$. licheniformis. These strains might be a source of industrially important enzymes mainly amylases and proteases.

\section{References}

Abou-Shanab RAI (2007) Characterization and 16S rDNA identification of thermo-tolerant bacteria isolated from hot springs. J Appl Sci Res 3:994-1000.

Adiguzel A, Ozkan H, Baris O et al. (2009) Identification and characterization of thermophilic bacteria isolated from hot springs in Turkey. J Microbiol Meth 79:321-328.

Adiguzel A, Inan K, Sahin F et al. (2011) Molecular diversity of thermophilic bacteria isolated from Pasinler hot spring (Erzurum, Turkey). Turk J Biol 35:267-274.

Bar M, von Hardenberg J, Meron E et al. (2002) Modelling the survival of bacteria in drylands: the advantage of being dormant, Proceedings of the Royal Society B: Biological Sciences 269:937-942.

Benbrahim S, Chafik A, Chfiri R et al. (2006) Survey of the carriers influencing the geographical and temporal distribution of contamination by heavy metals along the Atlantic Moroccan coasts: the case of mercury, lead and cadmium. Marine Life 16:37-47.

Berrada I, Willems A, De Vos P et al. (2012) Diversity of culturable moderately halophilic and halotolerant bacteria in a marsh and two salterns a protected ecosystem of Lower Loukkos (Morocco). Afr J Microbiol Res 6:2419-2434.

Bertoldo C, Antranikian G (2002) Starch-hydrolyzing enzymes from thermophilic Archea and bacteria. Curr Opin Chem Biol 6:151-160. 
Brock TD (1978) Thermophilic Microorganisms and Life at High Temperatures. Springer-verlag, Berlin, Heidelberg and New York.

Burgess SA, Lindsay D, Flint SH (2010) Thermophilic bacilli and their importance in dairy processing. Int J Food Microbiol 144:215-225.

Chamkha M, Mnif S, SayadiS (2008) Isolation of a thermophilic and halophilic tyrosol-degrading Geobacillus from a Tunisian high-temperature oil field. FEMS Microbiol Lett 283:23-29.

Cherif A, Borin S, Rizzi A et al. (2002) Characterization of a repetitive element polymorphism-polymerase chain reaction chromosomal marker that discriminates Bacillus anthracis from related species. J Appl Microbiol 93:456-462.

Cihan AC, Tekin N, Ozcan B et al. (2012) The genetic diversity of genus Bacillus and the related genera revealed by $16 \mathrm{~s}$ rRNA gene sequences and ARDRA analyses isolated from geothermal regions of Turkey. Braz J Microbiol 43:309-324.

Cihan AC, Cokmus C, Koc M et al. (2014) Anoxybacillus calidus sp. nov., a thermophilic bacterium isolated from soil near a thermal power plant. Int J Syst Evol Microbiol 64:211-219.

Connor N, Sikorski J, Rooney AP et al. (2010) Ecology of speciation in the Genus Bacillus. Appl Environ Microbiol 76:1349-1358.

Cowan DA (1991) Industrial enzymes. In: Moses V, Cape RE (eds) Biotechnology: The Science and the Business. Harwood Academic Publishers, United Kingdom, pp 311-340.

De Clerck E, De Vos P (2004) Genotypic diversity among Bacillus licheniformis strains from various sources. FEMS Microbiol Lett 231:91-98.

Derekova A, Mandeva R, Kambourova M (2008) Phylogenetic diversity of thermophilic carbohydrate degrading bacilli from Bulgarian hot springs. World J Microbiol Biot 24:1697-1702.

Gomez J, Steiner W (2004) The biocatalytic potential of extremophiles and extremozymes. Food Technol Biotech 2:223-235

Gordon RE, Haynes WC, Pang HN (1973) The genus Bacillus (Agricultural Handbook no. 427). Agricultural research service, United State, Department of Agriculture, Government Printing Office, Washington, D.C.

Hecker M, Völker U (2001) General stress response of Bacillus subtilis and other bacteria. Adv Microb Physiol 44:35-91.

Kawasaki Y, Aoki M, Makino Y et al. (2012) Characterization of moderately thermophilic bacteria isolated from saline hot spring in Japan. Microbiology Indonesia 5:56-60.

Khiyami MA, Serour EA, Shehata MM et al. (2012) Thermoaerobic bacteria from geothermal springs in Saudi Arabia. Afr J Biotechnol 11:4053-4062.

Kim OS, Cho YJ, Lee K et al. (2012) Introducing EzTaxon-e: a prokaryotic 16S rRNA Gene sequence database with phylotypes that represent uncultured species. Int J Syst Evol Microbiol 62:716-721.

Kublanov IV, Perevalova AA, Slobodkina GB et al. (2009) Biodiversity of thermophilic prokaryotes with hydrolytic activities in hot springs of Uzon Caldera, Kamchatka (Russia). Appl Environ Microbiol 75:286-291.

Kushner DJ (1985) The Halobacteriaceae In: Woese CR, Wolfe RS (eds) The Bacteria. Academic Press Inc., London, pp 171-214.
Lakhdar A, Ntarmouchant A, Ribeiro ML et al. (2006) Nouvelle approche geologique et geodynamique du complexe hydrothermal de Moulay Yacoub (Bordure Septentrionale du Sillon Sud Rifain). Comunicacoes Geologicas 93:185-204.

Lester ED, Satomi M, Ponce A (2007) Microflora of extreme arid Atacama Desert soils. Soil Biol Biochem 39:704-708.

Malkawi HI, Al-Omari MN (2010) Culture-dependent and culture-independent approaches to study the bacterial and archaeal diversity from Jordanian hot springs. Afr J Microbiol Res 4:923-932.

Manachini PL, Fortina MG, Levati L et al. (1998) Contribution to phenotypic and genotypic characterization of Bacillus licheniformis and description of new genomovars. Syst Appl Microbiol 21:520-529.

Maugeri T, Gugliandolo C, Caccamo D et al. (2001) A polyphasic taxonomic study of thermophilic bacilli from shallow, marine vents. Syst Appl Microbiol 24:572-587.

Meintanis C, Chalkou KI, Kormas KA et al. (2008) Application of rpoB sequence similarity analysis, REP-PCR and BOXPCR for the differentiation of species within the genus Geobacillus. Lett Appl Microbiol 46:395-401.

Minana-Galbis D, Pinzon DL, Loren JG et al. (2010) Reclassification of Geobacillus pallidus (Scholz et al., 1988) Banat et al., 2004 as Aeribacillus pallidus gen. nov., comb. nov. Int J Syst Evol Microbiol 60:1600-1604.

Ngoc-Phuc H, Fumihisa K, Yasunobu I et al. (2007) Detailed identification of desert-originated bacteria carried by Asian dust storms to Japan. Aerobiologia 23:291-298.

Palmisano MM, Nakamura LK, Duncan KE et al. (2001) Bacillus sonorensis sp. nov., a close relative of Bacillus licheniformis, isolated from soil in the Sonoran Desert, Arizona. Int J Syst Evol Microbiol 51:1671-1679.

Perfumo A, Marchant R (2010) Global transport of thermophilic bacteria in atmospheric dust. Environ Microbiol Rep 2:333339.

Pitcher DG, Saunders NA, Owen RJ (1989) Rapid extraction of bacterial genomic DNA with guanidiumthiocyanate. Lett Appl Microbiol 8:151-156.

Prescott LM, Harley GP, Klein DE (1993) Microbiology. 2nd ed. W. Brown publishers, Dubuque.

Rey MW, Ramaiya P, Nelson BA et al. (2004) Complete genome sequence of the industrial bacterium Bacillus licheniformis and comparisons with closely related Bacillus species. Genome Biol 5:1-12.

Robb F, Antranikian G, Grogan D et al. (2008) Thermophiles, Biology and Technology at High Temperatures. Boca Raton; CRC Press, London, New York.

Sadfi-Zouaoui N, Essghaier B, Hajlaoui MR et al. (2008) Ability of moderately halophilic bacteria to control grey mould disease on tomato fruits. J Phytopathol 156:42-52.

Salame B, Bahhou J, Bennani B et al. (2013) Qualité bactériologique et physico-chimique des eaux thermales d'Ain Allah région de Fès (Maroc). Science Lib Editions Mersenne 5:130505

Savas S, Adiguzel A, Inan K et al. (2009) Molecular characterization of thermophilic bacteria isolated from Van City Ercis Town Hasanabdal hot spring. Rom Biotech Lett 14:44454454.

Sierra GA (1957) Simple method for the detection of lipolytic activity of microorganisms and some observations on the in- 
fluence of the contact between cells and fatty substrates. Anton Leew 23:15-22.

Singh AK, Tripathi BM, Sahay H et al. (2010) Biochemical and molecular characterization of thermo-alkalitolerant xylanase producing bacteria from thermal springs of Manikaran, Indian J Microbiol 50:S2-S9.

Skoog DA, West D, Holler FJ (1996) Fundamentals of Analytical Chemistry. 7th ed, Saunders College Publishing: New York.

Souza AN, Martins MLL (2001) Isolation, properties and kinetics of growth of a thermophilic Bacillus. Braz J Microbiol 32:1517-8382.

Tekere M, Prinsloo A, Olivier J et al. (2012) An evaluation of the bacterial diversity at Tshipise, Mphephu and Sagole hot water springs, Limpopo Province, South Africa. Afr J Microbiol Res 6:4993-5004.
Ventosa A, Nieto JJ, Oren A (1998) Biology of moderately halophilic aerobic bacteria. Microbiol Mol Biol R 62:504544.

Versalovic J, Schneider M, De Bruijn FJ et al. (1994) Genomic fingerprinting of bacteria using repetitive sequence-based polymerase chain reaction. Methods Mol Cell B 5:25-40.

YonedaY, Yoshida T, Yasuda H et al. (2013) A novel thermophilic, hydrogenogenic, and carboxydotrophic bacterium Calderihabitans maritimus gen. nov., sp. nov. from a marine sediment core of an undersea caldera. Int J Syst Evol Microbiol ijs.0.050468-0.

Associate Editor: Raquel Silva Peixoto

All the content of the journal, except where otherwise noted, is licensed under a Creative Commons License CC BY-NC. 